\title{
Resiliensi Taruna STP dari Keluarga Pelaku Utama Perikanan
}

\author{
Sri W. Rahmawati \& Mira Rizki Wijayani
}

Fakultas Psikologi

Universitas Tama Jagakarsa

J1. Letjen TB Simatupang No. 157, Jakarta Selatan

swrahma@yahoo.com,mirarizki@yahoo.com

\begin{abstract}
The boarding campus life at the official school with the social and academic demands requires students (also called cadets) to have a tough mental. The risk of campus life creates a stressful condition. There are several ways to solve this problem. The way of them is facing the existing problems; adapting to the reality, and overcoming challenges quickly. They who have succeed to overcome the problem, even rising to become a stronger individual; they will find a better life. These individuals are said to be resilient individuals. This is a qualitative research to the cadets of Sekolah Tinggi Perikanan (STP), which come from the fishing prime actors (pumakan). The purpose of this research is to describe the resiliency dynamics of STP cadets. The subject research consists of four cadets from the two sexes, which have a background of different regional origin, as well as from families of pumakan (the fishing prime actors). The results of the research analysis can be seen in the various stages of resilient subject in facing the problem. Variations occur in resiliency factors. However, in the aspect of optimism and self-efficacy, overall subjects show the positive results. In addition, protective factors also have a significant effect. The protective factors are the resource support and positive characteristics of the individual; the social community and the family support. The overall factors strengthen adaptive ways of coping to the problems occurring.
\end{abstract}

Keywords: resilience; cadets of STP; pumakan; qualitative research

\begin{abstract}
Abstrak-Kehidupan kampus berasrama pada sekolah kedinasan dengan tuntutan sosial serta akademik, mengharuskan peserta didik (disebut juga dengan taruna) memiliki mental yang tangguh. Risiko kehidupan kampus tersebut menciptakan sebuah kondisi yang menekan. Ada beberapa cara untuk mengatasi persoalan menekan tersebut, diantaranya adalah: menghadapi permasalahan yang terjadi; beradaptasi dengan kenyataan; dan mengatasi tantangan dengan cepat. Mereka yang berhasil mengatasi permasalahan, bahkan bangkit menjadi individu yang lebih kuat, akan menemukan kehidupan yang lebih baik. Individu-individu ini dikatakan sebagai individu yang resilien. Penelitian ini merupakan penelitian kualitatif. Tujuan dari penelitian ini adalah melihat dinamika resiliensi taruna Sekolah Tinggi Perikanan (STP) yang berasal dari keluarga/
\end{abstract}


pelaku utama perikanan. Subjek penelitian terdiri dari empat taruna yang berasal dari dua jenis kelamin; memiliki latar belakang asal daerah yang berbeda; serta berasal dari keluarga pumakan (pelaku utama perikanan). Hasil analisis dari penelitian, secara kualitatif dapat terlihat variasi tingkat resiliensi subjek dalam menghadapi persoalan. Variasi terjadi pada faktor-faktor resilensi. Namun pada aspek optimisme dan efikasi diri, keseluruhan subjek menunjukkan hasil yang positif. Selain itu, faktor protektif juga memiliki pengaruh yang berarti. Faktor protektif tersebut yaitu dukungan sumber daya dan karakteristik positif dari individu; komunitas sosial serta dukungan keluarga. Keseluruhannya memperkuat cara coping yang adaptif terhadap persoalan yang terjadi.

Kata kunci: resiliensi; taruna STP; pumakan; riset kualitatif

\section{PENDAHULUAN}

Problem utama bagi mahasiswa peserta didik (selanjutnya disebut taruna) di Sekolah Tinggi Perikanan (STP) adalah beradaptasi dengan tuntutan akademik, maupun tuntutan sosial dalam lingkungan pendidikan dengan sistem asrama (Daging, I Ketut, 2012). Taruna tidak hanya dituntut untuk mampu bekerja sama dengan berbagai rekan yang berasal dari daerah di seluruh Indonesia dengan beragam karakter dan budaya asal; namun juga beradaptasi dengan pola pembinaan yang berlaku di asrama. Pola pembinaan tersebut menjadi wewenang UPTA (Unit Pembinaan Taruna) yang dalam implementasi pelaksanaannya banyak diserahkan kepada kakak kelas (taruna senior).

Salah satu kebijakan Kementerian Kelautan dan Perikanan dalam memajukan perikanan di wilayah Indonesia, adalah dengan memberikan kesempatan kepada anak pumakan (pelaku utama perikanan, meliputi anak nelayan, pengolah hasil perikanan, pembudidaya ikan, pedagang ikan dan petani garam) untuk mengikuti pendidikan di STP (http//: www.stp.kkp.go.id). Bagi sebagian besar anak pumakan, mengikuti pendidikan di tingkat perguruan tinggi bukanlah sesuatu yang mudah. Keterbatasan sarana yang mereka miliki, pengetahuan, keterampilan mengelola persoalan, menjadi faktor yang menghambat ketika menghadapi berbagai problema adaptasi di dunia akademik. Dibutuhkan ketangguhan mental yang memadai agar taruna STP dari pumakan ini dapat berhasil melalui proses pendidikan.

Terdapat sejumlah karakteristik individu yang berhubungan dengan kegagalan studi (Hidayati, Rejeki, Laily, 2011 dalam Yulianto, 2011). Taruna yang memiliki aspirasi kurang terhadap pendidikan, akan gagal untuk beradaptasi dengan tuntutan akademik. Sikap yang negatif terhadap kehidupan asrama juga juga menjadi faktor penting kegagalan. Selain itu, kurangnya kemampuan menyelesaikan persoalan ditengarai juga menjadi faktor penting yang berperan dalam kegagalan. Agar dapat melalui proses pendidikan di STP secara lancar, taruna diharapkan memiliki resiliensi terhadap kehidupan kampus maupun kehidupan ketarunaan sehingga mereka mampu bertahan dan melaluinya secara positif.

\section{Resiliensi}

Resiliensi dipandang oleh para ahli sebagai kemampuan untuk bangkit kembali dari situasi atau peristiwa yang traumatis. Siebert (2005) dalam bukunya The Resiliency Advantage memaparkan bahwa yang dimaksud dengan resiliensi adalah kemampuan untuk mengatasi dengan baik perubahan hidup pada level yang tinggi, menjaga kesehatan di bawah kondisi penuh tekanan, bangkit dari keterpurukan, mengatasi 
kemalangan, merubah cara hidup ketika cara yang lama dirasa tidak sesuai lagi dengan kondisi yang ada, dan menghadapi permasalahan tanpa melakukan kekerasan. Resiliensi adalah proses mengatasi efek negatif dari risiko yang ada, berhasil mengatasi pengalaman traumatik dan menghindari dampak negatif terkait resiko (Fergus \& Zimmerman, 2005). Masten, Best, dan Garmezy (dalam Chen \& George, 2005) mendefinisikan resiliensi sebagai sebuah proses, kemampuan seseorang, atau hasil dari adaptasi yang berhasil meskipun berhadapan dengan situasi yang mengancam.

Masten dan Reed (dalam Luthans, Vogelgesang \& Lester, 2006) mendefinisikan resiliensi sebagai sebuah fenomena yang dicirikan oleh pola adaptasi yang positif dalam konteks resiko atau kemalangan. Resiliensi adalah kemampuan yang dimiliki individu untuk mampu bertahan dan berkembang secara positif dalam situasi yang penuh tekanan atau kurang baik. Definisi Resiliensi yang digunakan dalam penelitian ini adalah kemampuan individu untuk melakukan penyesuaian dan adaptasi secara positif terhadap perubahan, keinginan dan kegagalan yang muncul dalam kehidupan, mengatasi kondisi yang penuh tekanan, bangkit dan berkembang secara positif menjadi individu yang lebih baik.

\section{Tujuh Faktor Resiliensi}

Reivich dan Shatte (2002), memaparkan tujuh kemampuan yang membentuk resiliensi, yaitu regulasi emosi, pengendalian impuls, optimisme, empati, analisis penyebab masalah, efikasi diri, dan kemampuan menjangkau (reaching out). Hampir tidak ada satupun individu yang secara keseluruhan memiliki tujuh kemampuan tersebut dengan baik.

a. Regulasi Emosi

Regulasi emosi adalah kemampuan untuk tetap tenang di bawah kondisi yang menekan (Reivich \& Shatte, 2002). Emosi yang dirasakan oleh seseorang cenderung berpengaruh terhadap orang lain. Semakin kita terasosiasi dengan kemarahan maka kita akan semakin menjadi seorang yang pemarah (Reivich \& Shatte, 2002). Greef (2005) menyatakan bahwa individu yang memiliki kemampuan untuk mengatur emosinya dengan baik dan memahami emosi orang lain akan memiliki self-esteem dan hubungan yang lebih baik dengan orang lain. Reivich dan Shatte (2002), mengungkapkan dua buah keterampilan yang dapat memudahkan individu untuk melakukan regulasi emosi, yaitu tenang dan fokus. Dua buah keterampilan ini akan membantu individu untuk mengontrol emosi yang tidak terkendali, menjaga fokus pikiran individu ketika banyak hal-hal yang mengganggu, serta mengurangi stres yang dialami oleh individu.

b. Pengendalian Impuls

Pengendalian impuls adalah kemampuan Individu untuk mengendalikan keinginan, dorongan, kesukaan, serta tekanan yang muncul dari dalam diri (Reivich \& Shatte, 2002). Individu yang memiliki kemampuan pengendalian impuls yang rendah, cepat mengalami perubahan emosi yang pada akhirnya mengendalikan pikiran dan perilaku mereka. Mereka menampilkan perilaku mudah marah, kehilangan kesabaran, impulsif, dan berlaku agresif. Individu dapat mengendalikan impulsivitas dengan mencegah terjadinya kesalahan pemikiran, sehingga dapat memberikan respon yang tepat pada permasalahan yang ada. Menurut Reivich dan Shatte (2002), Pencegahan dapat dilakukan dengan menguji keyakinan individu dan mengevaluasi kebermanfaatan terhadap pemecahan masalah. Individu dapat melakukan 
pertanyaan-pertanyaan yang bersifat rasional yang ditujukan kepada dirinya sendiri, seperti 'apakah penyimpulan terhadap masalah yang saya hadapi berdasarkan fakta atau hanya menebak?', 'apakah saya sudah melihat permasalahan secara keseluruhan?', 'apakah manfaat dari semua ini?', dll.

Kemampuan individu untuk mengendalikan impuls sangat terkait dengan kemampuan regulasi emosi yang ia miliki.Seorang individu yang memiliki skor Resilience Quotient yang tinggi pada faktor regulasi emosi cenderung memilikis kor Resilience Quotient pada faktor pengendalian impuls (Reivich $\&$ Shatte, 2002).

c. Optimisme

Individu yang resilien adalah individu yang optimis (Reivich \& Shatte, 2002). Siebert (2005) mengungkapkan bahwa terdapat hubungan antara tindakan dan ekspektasi seseorang dengan kondisi kehidupan yang dialaminya. Optimisme adalah ketika kita melihat bahwa masa depan kita cemerlang (Reivich \& Shatte,2002). Peterson dan Chang (dalam Siebert, 2005) mengungkapkan bahwa optimisme sangat terkait dengan karakter individu yang menginginkan kebahagiaan, ketekunan, pencapaian prestasi serta derajat kesehatan. Individu yang optimis percaya bahwa situasi yang sulit suatu saat akan berubah menjadi situasi yang lebih baik. Mereka memiliki harapan terhadap masa depan mereka dan mereka percaya bahwa merekalah pemegang kendali atas arah hidup mereka. Individu yang optimis memiliki kesehatan yang lebih baik, jarang mengalami depresi, serta memiliki produktivitas kerja yang tinggi, apabila dibandingkan dengan individu yang cenderung pesimis.

d. Efikasi diri

Efikasi-diri adalah hasil dari pemecahan masalah yang berhasil. Efikasi-diri merepresentasikan sebuah keyakinan bahwa kita mampu memecahkan masalah yang kita alami dan mencapai kesuksesan (Reivich \& Shatte, 2002). Sementara Bandura (dalam Atwater \& Duffy, 1997) mendefinisikan efikasidiri sebagai kemampuan individu untuk mengatur dan melaksanakan suatu tindakan untuk mencapai hasil yang diinginkan. Efikasi-diri memiliki kedekatan dengan konsep Perceived Control, yaitu suatu keyakinan bahwa individu mampu mempengaruhi keberadaan suatu peristiwa yang mempengaruhi kehidupan individu tersebut. Perceived Control memiliki dua buah sumber, yaitu Internal Locus of Control dan External Locus of Control. Individu dengan Internal Locusof Control meyakini bahwa dirinya memegang kendali terhadap kehidupannya. Sementara individu dengan External Locus of Control yakin bahwa sesuatu yangberada di luar dirinya memiliki kendali atas kehidupannya (Atwater \& Duffy 1997).

e. Analisis penyebab

Analisis-penyebab merujuk pada kemampuan individu untuk mengidentifikasikan secara akurat penyebab dari permasalahan yang mereka hadapi. Seligman (dalam Reivich \& Shatte, 2002) mengidentifikasikan gaya berpikir explanatory (penjelasan) yang erat kaitannya dengan kemampuan analisis-penyebab yang dimiliki individu. Gaya berpikir explanatory (penjelasan) dapat dibagi dalam tiga dimensi: personal (saya-bukan saya), permanen (selalu-tidak selalu), dan pervasif (semua-tidak semua). Individu dengan gaya berpikir "Saya-Selalu-Semua" merefleksikan keyakinan bahwa penyebab permasalahan berasal dari individu tersebut (Saya), hal ini selalu terjadi dan permasalahan yang ada tidak dapat diubah (Selalu), serta permasalahan yang ada akan mempengaruhi seluruh aspek hidupnya (Semua). Sementara individu yang memiliki gaya berpikir "Bukan Saya-Tidak Selalu-Tidak semua" meyakini bahwa permasahalan yang terjadi disebabkan oleh oranglain (Bukan Saya), di mana kondisi tersebut masih memungkinkan untuk diubah (Tidak Selalu) dan permasalahan yang ada tidak akan 
mempengaruhi sebagian besar hidupnya (Tidak semua). Gaya berpikir explanatory (penjelasan) memegang peranan penting dalam konsep resiliensi (Reivich \& Shatte, 2002).

f. Empati

Empati dapat didefinisikan sebagai kemampuan untuk memahami dan memiliki kepedulian terhadap orang lain (Greef, 2005). Seseorang yang memiliki kemampuan berempati cenderung memiliki hubungan sosial yang positif (Reivich \& Shatte, 2002).Ketidakmampuan berempati berpotensi menimbulkan kesulitan dalam hubungan sosial (Reivich \& Shatte, 2002). Individu dengan empati yang rendah cenderung mengulang pola yang dilakukan oleh individu yang tidak resilien, yaitu menyamaratakan semua keinginan dan emosi orang lain (Reivich \& Shatte, 2002). Greef (2005), mengungkapkan bahwa salah satu perilaku yang ditampilkan oleh individu yang resilien adalah menunjukkan empati kepada orang lain.

g. Kemampuan menjangkau

Banyak individu yang tidak mampu melakukan reaching out (menjangkau) hal ini dikarenakan mereka telah diajarkan sejak kecil untuk sedapat mungkin menghindari kegagalan dan situasi yang memalukan. Hal ini menunjukkan kecenderungan individu untuk berlebih-lebihan dalam memandang kemungkinan hal-hal buruk yang dapat terjadi di masa mendatang. Individu-individu ini memiliki rasa ketakutan untuk mengoptimalkan kemampuan mereka hingga batas akhir. Gaya berpikir ini memberikan batasan bagi diri mereka sendiri, atau dikenal dengan istilah self-handicaping (kecacatan diri).

\section{Faktor Protektif}

Selain tujuh faktor resiliensi di atas, terdapat faktor pendukung yang akan membentuk individu resilien. Faktor tersebut lebih dikenal dengan istilah faktor protektif (Rutter, 1987). Faktor-faktor protektif ini dapat mengubah, mengurangi, atau meningkatkan respon individu terhadap pengaruh lingkungan yang memberi kecenderungan untuk mengalami perkembangan maladaptif. Adapun faktor-faktor protektif dan mekanisme dapat dibagi dalam beberapa kategori: Pertama, sumber daya dan karakteristik yang positif dari individu; Kedua, keluarga yang stabil dan memberikan dukungan yang ditandai dengan adanya pertalian di antara anggota keluarga; Ketiga, jaringan sosial eksternal atau komunitas yang mendukung dan memperkuat cara coping yang adaptive (Garmezy, 1993; Werner, 1989, 1993; dalam Isaacson, 2002).

Permasalahan taruna pumakan STP selama ini masih sedikit diteliti, terutama berkaitan dengan dinamika taruna dalam menghadapi persoalan sosial, maupun akademis di lingkungan kampus berasrama. Sebagai sekolah kedinasan, sistem kampus berasrama ini memiliki aturan, tuntutan maupun cara penyelesaian masalah tersendiri. Penyesuaian ini terutama sangat dirasakan oleh taruna tingkat I (disebut juga dengan istilah taruna remaja), yang merupakan taruna paling junior dalam sistem hierarki ketarunaan di STP (Daging, I Ketut, 2012). Penelitian ini bertujuan untuk menggali faktor-faktor resiliensi yang dimiliki partisipan, serta melihat dukungan faktor protektif. Resiliensi merupakan sikap mental yang dibutuhkan dalam memenuhi tuntutan beradaptasi pada pendidikan dengan sistem asrama. 


\section{METODE}

\section{Partisipan}

Prosedur penentuan subjek atau sumber data dalam penelitian kualitatif umumnya menampilkan karakteristik: (a) diarahkan tidak pada jumlah sampel yang besar, melainkan pada kasus-kasus tipikal sesuai kekhususan masalah penelitian; (b) tidak ditentukan secara kaku sejak awal, tetapi dapat berubah baik dalam hal jumlah maupun karakteristik sampelnya, sesuai dengan pemahaman konseptual yang berkembang dalam penelitian; (c) tidak diarahkan pada keterwakilan dalam arti jumlah atau peristiwa acak, melainkan pada kecocokan konteks (Sarantakos dalam Poerwandari, 2011). Penelitian dibatasi pada sejumlah kecil kasus taruna pumakan tingkat I untuk menampilkan kedalaman dan detail pada hasil penelitian. Selain itu untuk memahami dinamika dan kompleksitas yang ada penelitian yang dilakukan tidak selalu mengikuti tahapantahapan kaku terstruktur melainkan lebih bersifat sirkuler dan memungkinkan adanya fleksibilitas desain (Poerwandari, 2011).

Partisipan dalam penelitian ini terdiri dari empat taruna, dengan karakteristik: (a) tercatat sebagai taruna tingkat I (disebut juga taruna remaja) di STP, (b) anak dari keluarga pelaku utama perikanan (pumakan); (c) usia antara 19-20 tahun.; (d) tinggal di asrama kampus; (e) berasal dari daerah. Empat orang partisipan terdiri dari dua taruna (mahasiswa) dan dua taruni (mahasiswi). Informasi mengenai partisipan diperoleh melalui penanggung jawab asrama. Rincian data partisipan tersaji dalam tabel sebagai berikut:

Tabel 1. Identitas Partisipan

\begin{tabular}{|c|c|c|c|c|c|}
\hline No & Aspek & Subjek 1 & Subjek 2 & Subjek 3 & Subjek 4 \\
\hline 1 & Nama samaran & Adi & Budi & Cicha & Desi \\
\hline 2 & Jenis Kelamin & Laki-laki & Laki-laki & Perempuan & Perempuan \\
\hline 3 & Asal Daerah & Sumatera Selatan & Jawa Tengah & Sulawesi Selatan & Sumatera Barat \\
\hline 4 & Usia (tahun) & 19 & 19 & 19 & 20 \\
\hline 5 & $\begin{array}{l}\text { IPK semester } 1 \\
\text { (skala 4) }\end{array}$ & 2,78 & 3,00 & 3,21 & 2,98 \\
\hline 6 & $\begin{array}{l}\text { Pekerjaan } \\
\text { Orang Tua }\end{array}$ & Nelayan & Pedagang Ikan & $\begin{array}{l}\text { Pembudidaya } \\
\text { Tambak }\end{array}$ & Petani Garam \\
\hline
\end{tabular}

\section{Desain}

Tekanan di sekolah kedinasan merupakan suatu fenomena dalam dunia pendidikan yang belum banyak terungkap. Sistem pembinaan yang berlangsung secara hierarki dari taruna senior ke juniornya, menuntut kemampuan adaptasi tertentu. Sebagai konstruk dari penelitian ini, kemampuan resiliensi yang dimiliki oleh partisipan taruna memiliki sifat yang subjektif. Partisipan memiliki perbedaan cara adaptasi dalam mengatasi persoalan. Kemampuan resiliensi yang dimiliki oleh masing-masing partisipan pun bervariasi dikarenakan perbedaan proses dan faktor yang mempengaruhi. Berangkat dari beberapa hal mendasar yang telah dipaparkan di atas, penelitian ini didesain menggunakan metode kualitatif dengan tipe deskriptif. 


\section{Prosedur}

Pengumpulan data dilakukan dengan melakukan kontak langsung secara personal dengan partisipan, melalui metode wawancara berstruktur. Wawancara dalam penelitian ini menggunakan pedoman umum yang mencantumkan isu-isu yang harus diliput.

Wawancara yang dilakukan pada setiap partisipan berisi tanya jawab sekitar tujuh faktor resiliensi, faktor protektif yang berpengaruh terhadap individu tersebut, serta kondisi psikologis individu tersebut sebagai taruna STP yang berasal dari keluarga pumakan. Wawancara dilakukan sebanyak empat kali di ruang bimbingan konseling kampus STP. Secara umum wawancara berlangsung lancar, partisipan tampak terbuka dalam menyampaikan pendapatnya. Hasil wawancara direkam dalam tape recorder, dilengkapi dengan catatan secara tertulis. Penelitian ini juga menggunakan metode observasi guna melengkapi informasi yang didapat. Observasi selalu menjadi bagian dalam penelitian psikologi yang dapat berlangsung baik dalam konteks laboratorium maupun dalam konteks alamiah (Banister dalam Poerwandari, 2011).

\section{Teknik Analisis}

Data yang diperoleh dianalisis menggunakan teori yang dikembangkan oleh peneliti. Data dari subjek penelitian berupa jawaban maupun kata-kata partisipan diolah sedemikian rupa. Hal ini sesuai dengan acuan yang diberikan Patton (1990, dalam Poerwandari, 2011) bahwa proses analisis dapat melibatkan konsep-konsep yang muncul dari jawaban responden, maupun konsep yang dikembangkan peneliti untuk menjelaskan fenemona yang dianalisis. Hasil analisis kemudian disajikan dalam bentuk deskripsi maupun tabel sehingga lebih sistematis. Berdasarkan respon partisipan, peneliti kemudian mengkategorisasikan faktor resiliensi pada kategori baik, cukup maupun kurang, dengan mengacu pada jawaban yang diberikan. Setelah itu, langkah berikutnya adalah melakukan perumusan kesimpulan yang terkait dengan masalah penelitian, perumusan saran serta rekomendasi, sehingga dapat diaplikasikan oleh masyarakat berlandaskan pada konsep teori yang digunakan.

\section{ANALISIS \& HASIL}

\section{Profil Sekolah Tinggi Perikanan}

Sekolah Tinggi Perikanan (STP) merupakan satu-satunya sekolah tinggi kedinasan milik Kementerian Kelautan dan Perikanan RI. Berada di bawah Badan Pengembangan Sumber Daya Manusia Kelautan dan Perikanan. Berlokasi di kawasan Pasar Minggu, Jakarta Selatan. Awalnya lembaga pendidikan ini dikenal dengan sebutan Diklat AUP (Akademik Usaha Perikanan). Pada 1993 berubah nama menjadi Sekolah Tinggi Perikanan (STP).

STP memiliki program studi setara Diploma IV, yaitu Program Teknologi Penangkapan Ikan (TPI), Teknologi Pengolahan Hasil Perikanan (TPH), Teknologi Permesinan Perikanan (MP), Terknologi Akuakultur (TAK), Teknologi Pengelolaan Sumber daya Perairan (TPS) dan Penyuluhan Perikanan. Untuk mendukung program studi tersebut, STP menyediakan berbagai fasilitas pendukung, seperti: laboratorium kimia, pengolahan ikan dan unit pendingin, laboratorium biologi, hidrologi, workshop alat tangkap, simulator penangkapan dan navigasi, instalasi pembuat es, fasilitas basic safety training dan unit latihan lapangan (www.stp.kkp.go.id) 


\section{Sistem Pembinaan Mahasiswa/Taruna di Sekolah Tinggi Perikanan}

Taruna STP berasal dari seluruh propinsi di Indonesia, yang masuk melalui sistem seleksi. Setiap tahun setidaknya tercatat 400-500 taruna baru yang dinyatakan diterima, setelah menyisihkan kurang lebih 1000 orang pendaftar. Sejak dua tahun belakangan ini, yaitu tahun akademik 2011/2012 dan 2012/2013, maka dibuka kesempatan yang lebih luas bagi kalangan pelaku utama perikanan (pumakan) untuk menyekolahkan putra-putrinya di tempat ini. Pumakan ini terdiri dari beberapa kalangan, yaitu: kalangan anak nelayan, pembudidaya ikan, pedagang ikan, dan petani garam.

Taruna yang masuk ke STP akan tinggal secara penuh di asrama yang beradap satu kompleks dengan lokasi pendidikan. Selain menerima program pendidikan akademik yang diberikan oleh para dosen dalam bentuk teori dan praktek, dalam kesehariannya para taruna ini juga terikat dengan aturan kehidupan asrama (Daging, I Ketut, 2012). Pola pembinaan taruna STP berada di bawah pengawasan Unit Pembinaan Taruna dan Asrama (UPTA) yang merupakan salah satu unit kerja di Sekolah Tinggi Perikanan (STP) di bawah koordinasi dengan Pembantu Ketua III (Puket III).UPTA miliki tupoksi untuk membina dan mengawasi Taruna-Taruni dalam bidang kedisiplinan, kepribadian serta pengembangan minat dan bakat. Bentuk pembinaan TarunaTaruni STP di UPTA berkaitan dengan hal-hal yang sifatnya non akademis baik ekstrakurikuler maupun kokurikuler dengan kegiatan terjadwal dan tidak terjadwal. Kegiatan yang terjadwal adalah kegiatan yang dilakukan berdasarkan program kerja yang telah tersusun dalam jadwal kegiatan Taruna-Taruni, dalam rangka mendukung berjalannya kegiatan pembinaan secara efisien dan efektif. Sedangkan kegiatan yang tidak terjadwal adalah kegiatan yang dilakukan atau dilaksanakan berdasarkan program tertentu maupun undangan kegiatan yang menunjang atau berkaitan dengan kegiatan Taruna-Taruni. Pelaksanaan dari seluruh kegiatan Taruna-Tauni STP yang bersifat pembinaan diselenggarakan dengan berpedoman pada SPSKT (Sistem Pembinaan Sikap dan Kepribadian Taruna) serta aturan-aturan lain yang berlaku di Sekolah Tinggi Perikanan. Dalam kegiatan pembinaan dilaksanakan 10 (sepuluh) pilar pembinaan, yaitu: (1) Kerohanian dan Budi Pekerti; (2) Pengembangan Diri dan Organisasi; (3) Olahraga dan Kesamaptaan; (4) Kesenian dan Budaya; (5) Beladiri (6) Drumband; (7) Keputrian; (8) Hukum dan Perundang-undangan; (9) Kewirausahaan; (10) Selam (www.stp.kkp.go.id)

Tahap-tahap proses pembinaan yang dilakukan UPTA terhadap Taruna-Taruni STP dilaksanakan melalui beberapa tahap, antara lain: pada saat mulai pendaftaran masuk menjadi Taruna-Taruni STP, Latihan Dasar Kedisiplinan Taruna (LATDASLINTAR), Masa Orientasi Studi dan Ketarunaan (MOSTAR), Pelantikan Taruna Baru, Masa BASIS dan Pembinaan Lanjutan.

Tuntutan pendidikan di STP mengharuskan tarunanya memiliki fisik dan mental yang tangguh. Tarunataruni ditempa dengan pembinaan fisik dan mental melalui sistem pembinaan kedisiplinan semi militer. Hal ini dimaksudkan untuk membekali para taruna-taruni dengan disiplin yang tinggi serta karakter yang kuat. Aturan pola pembinaan di STP tidak membolehkan terjadinya kekerasan di kalangan taruna-taruni. Namun demikian, celah untuk melakukan kekerasan kepada taruna remaja oleh para taruna senior selalu terbuka, dengan mengatasnamakan pembinaan kedisiplinan. Pihak Unit Pembinaan Taruna (UPTA) telah mengatur sedemikian rupa agar peluang terjadinya kekerasan ini dapat dihindarkan. (Daging, I Ketut, 2012). Namun demikian, 1300 taruna yang tinggal bersamaan di asrama membuat pengawasan tersebut menjadi kurang optimal, apalagi tindak kekerasan atas nama pola pendisiplinan taruna tersebut biasanya dilakukan pada waktu-waktu tertentu saat pengawasan longgar, misalnya pada tengah malam di tempat yang tersembunyi di bagian tertentu dari asrama. (www.stp.kkp.go.id) 


\section{Analisis Deskriptif Tujuh Faktor Resiliensi}

\section{a. Regulasi Emosi}

Tekanan yang dirasakan taruna sudah diterima sejak menginjakan kaki di asrama. Saat itulah sistem ketarunaan yang menekankan pada senioritas diterapkan. Taruna remaja diikat dengan sejumlah aturan untuk mematuhi seniornya, seperti aturan berbicara dengan taruna senior dan cara mereka menyapa.

“... taruna senior udah kayak dewa di sini... seenaknya buat aturan...ee kalau ketemu, kita gak boleh banyak tersenyum, tapi kalau tidak tersenyum pun bisa dianggap ... apa ya... kurang ajar.. aturan-aturan yang bikin aku emosi..." (Subjek Adi)

“....gak tau dari kapan aturan kayak gini ada, tapi sebagai taruna remaja harus ikuti semua... kalau gak...wah.... jangan coba-coba, bisa habis dihajar...berusaha aja untuk menghadapinya, kalau kesel saya hmmm ....ya berbagi cerita dengan temen sekamar... " (Subjek Budi)

“...... sejak awal masuk di sini, ya aku mesti siap...aturan jam mandi pagi misalnya, taruna remaja jam dua dini hari harus udah bangun...iya...mengantri mandi dengan waktu yang terbatas, padahal kita biasanya baru tidur menjelang jam 12 malam... apalagi saat masa basis... saya liat sisi positifnya, dengan mandi pikiran mumet langsung ilang... ada aturan ikutin aja ... ada kok sisi baiknya juga... "(Subjek Cicha)

" taruni putri wah paling ribet...eehmm iya....kita senyum ke taruna senior, malam hari dipanggil kakak taruni...ngapain kamu senyum-senyum...tebar pesona, mau belajar apa cari cowok di sini....waduh bingung, gak senyum salah, tapi kalau senyum bisa ditegor, keki juga.... apalagi gak sengaja yang disenyumin pacar taruni senior.... jadi pengalaman, besok-besok lagi kalau ketemu ya angguk kepala aja, tanda kita sopanlah sama dia...." (Subjek Desi).

\section{b. Kendali Impuls}

Peraturan dengan tujuan untuk membudayakan disiplin dikenakan secara ketat pada taruna remaja. Dalam kehidupan asrama, terutama pada masa basis (masa 3 bulan awal) taruna remaja dibudayakan untuk bertindak sigap. Sejumlah aturan harus dijalankan, seperti makan bersama dengan rentang waktu tertentu, taruna remaja dilarang berjalan, waktu istirahat yang kurang untuk mendengarkan arahan-arahan taruna senior di malam hari.

“... makan di ruang makan asrama...waktu terbatas...gak usah pake dikunyah, telen aja pake air...minum yang banyak.... Hanya lima menit makan harus selesai, mau gimana lagi... aturannya dibuat engg... untuk nunjukkin arogansi aja.... Kesel banget...nanti kalau aku jadi taruna senior, ngerasin juga kali ya ngerjain taruna junior..” (tertawa).... (Subjek Adi)

“....kalau yang namanya apel malam...ya udah tau semua... isinya kita taruna remaja akan dimakimaki...dianggap gak becus...gak disiplin, membantah senior... kalau cuma dimaki-maki itu anugerah, ada juga tindakan fisik...hmmm...gak usah dibahas, semua di sini paham.....kesalahan satu aja yang dibuat teman seangkatan, semua akan dipanggil untuk ikut tanggung jawab...gak fair...berusaha jangan buat kesalahan, kena semua nanti... Perasaan solidaritas sama teman seangkatan jadi berkembang di sini, temen-temen saling menguatkan..... " (Subjek Budi) “...... hormat sama kakak taruna senior itu ya mesti siap disuruh-suruh ... hmmm iya ...ini aturan aneh kalau kata aku... tapi coba aja aku ikuti, gak usah jadi emosi...yaaa mungkin mereka juga digituin...diperlakukan serupa dengan seniornya dulu kan...........kalau menurutku harus diubah, mungkin nanti kalau aku udah jadi senior... “(Subjek Cicha) 
“ masa basis....tiga bulan itu lamanya....paling menderita....sama, semua taruna remaja kayak gitu.... Kalau udah kesel dan capek, ya aku coba redam sendiri dulu...... kalau waktu ada dan memungkinkan, aku juga berbagi ama temen satu kamar...sama, dia juga merasakan kayak gitu pastinya ....." (Subjek Desi).

\section{c. Optimisme}

Informasi yang terbatas mengenai sejumlah aturan pada sistem pendidikan STP membuat taruna perlu beradaptasi segera dengan tuntutan yang ada. Meski tujuan awal mereka datang dari berbagai daerah adalah untuk belajar tentang keahlian di bidang perikanan, tak pelak pembiasaan dalam kehidupan berasrama maupun kehidupan sehari-hari bidang akademik mempengaruhi motivasi taruna. Namun demikian, rasa optimis untuk dapat melalui aturan yang berlaku serta keinginan untuk mendapatkan keahlian di bidang perikanan, memacu partisipan untuk bersikap positif.

“....ada masa-masanya... emang mesti gini jalannya.... Ada juga yang kena fisik, seperti dipukul dan diintimidasi...tapi sekarang katanya udah lebih mendingan ...karena kekerasan di sini dilarang... masih mending dibandingkan sekolah kedinasan lain.... Enggg... ya nanti kan semuanya akan lewat juga...ini juga gak selamanya kayak gini.....” (Subjek Adi)

“... dikerjain senior di asrama...pas masuk kuliah, udah gak karuan...ngantuk, daya tangkap tinggal lima watt (tertawa) .... Ada dosen-dosen tertentu yang paham ini...mereka rata-rata kan juga dididik di tempat ini....ini memang berat, tapi paling satu tahun aja beratnya... biasa tadinya saya hidup bebas, jadi nelayan di laut, tanpa aturan macam-macam....sekarang harus $i k u t i$ semua aturan di sini....perubahan mental ya pasti ada.... "(Subjek Budi)

“...... sejak SMA aku udah diceritain sama saudaraku yang lulusan STP ini....akan begini dan begitu pendidikannya.....itu kan pasti semua ada konsekuensinya..... kayaknya di mana pun akan seperti itu, ada tantangannya..... aku coba lihat hal positif yang bisa diambil...tadinya aku cengeng, di sini gak ada tempat buat mellow, nangis atau sedih terus-terusan...jadinya mental kita juga lebih kuat...."(Subjek Cicha)

“...mesti inget ama tujuan... jalannya kan mesti kayak gini... susah-susah dulu... Nah, kalau udah masuk kelas, baru terasa saya ke sini mau jadi apa ... kalau di asrama kita belajar membentuk mental, di kelas, kita belajar keahlian .....” (Subjek Desi).

\section{d. Efikasi diri}

Pendidikan sistem asrama yang menekankan pada hierarki senioritas dirasakan membutuhkan adaptasi tersendiri bagi taruna pumakan (pelaku utama perikanan). Mereka yang pada awalnya hidup bebas kini harus mengikuti mekanisme pendidikan yang ketat. Dibandingkan dengan taruna lain yang buka berasal dari pumakan, taruna pumakan memiliki keterbatasan fasilitas/ekonomi, beberapa di antaranya juga daya tangkap mengelola informasi, dan keterbatasan akses informasi. Bagi sebagian pumakan, kondisi tersebut mereka hadapi sebagai suatu proses pendidikan, yang membuat mereka menjadi lebih keras berupaya mengatasinya. “...tugas-tugas yang diberikan di kelas itu banyak.. ini kan pendidikan yang banyak prakteknya, jadi memang kurikulumnya seperti itu.....yang susah mencari waktu untuk mengerjakan tugas dosen, karena waktu di luar kuliah habis untuk mengikuti permintaan taruna senior, kadang-kadang juga ada yang minta tugas kuliah mereka dikerjakan.. Aku biasanya eeeng...ya diskusi ama temen, gimana caranya tugas selesai, dosen gak kasih sanksi, senior juga gak menghukum...ketemu juga jalannya sih.... .....” (Subjek Adi) “ ... karena saya bukan dari SUPM (Sekolah Usaha Perikanan Menengah) jadi susah menangkap penjelasan dosen...cara mengajarnya terlalu cepat.. Mau gak mau harus mengulang lagi di asrama, 
belajar dengan cara mengulang-ulang...itu juga harus pinter-pinter jaga sikap, karena kalau kena hukuman dari taruna senior, artinya hilang waktu belajar di asrama...... " (Subjek Budi)

“..... semester awal di STP aku belum punya laptop.. mau minta sama orang tua, gak tega.... padahal tugas banyak yang mesti menggunakan laptop dalam penyelesaiannya... aku coba siasati, dengan meminjam laptop teman waktu udah gak dipake lagi...konsekuensinya aku mesti gunakan waktu tidur untuk menyelesaikan tugas, saat itu temanku biasanya membolehkan aku meminjam laptopnya....susah emang, tapi Alhamdulullah nilaiku di semester itu baik...." (Subjek Cicha) “... awalnya emang berat...kita biasa hidup bebas sekarang mesti mengikuti aturan yang ketat... dalam kuliah juga sama, materinya maju cepet banget ..., ya mesti banyak-banyak nanya ...baca... akhirnya bisa juga sih ....." (Subjek Desi).

e. Analisis Penyebab

Pendidikan asrama dengan sistem semi militer dilakuan dengan mengedepankan banyak pertimbangan. Sebagai sistem yang turun temurun dijalankan selama STP berdiri, sistem ini dipandang telah melahirkan mental tangguh dan disiplin para taruna, sehingga mereka siap bekerja di dunia perikanan. Partisipan penelitian ini memberikan tanggapan yang cukup beragam mengenai sistem semi militer, serta sistem hierarki yang diterapkan oleh Pembina.

“...sebenernya sistem hierarki di sini hanya buat gagah-gagahan senior aja. .. udah gak cocok di zaman gini pake sistem sok arogan ...emang di STP ini masih mending dibandingkan dengan sekolah kedinasan lain....... Kalau tertekan dengan semua aturan, biasanya aku suka ajak temanku...ehhh kabur... kabur sebentar keluar asrama....” (Subjek Adi)

“ $h m$ gimana ya...ni sistem hierarki katanya kan ...maksudnya taruna senior di atas kita itu punya kakak kelas yang jadi seniornya lagi...jadi kita ini sih korban....dikerjain, bisa karena kakak senior di atasnya lagi yang ngerjain dia.....enggh ...pelampiasan.. "(Subjek Budi)

“......banyak pro dan kontra...tapi menurutku masuk ke sini yang mesti siap dengan semua sistemnya...kan udah ketauan emang seperti itu pola pendidikannya...udah banyak alumni yang diluluskan dan menjadi orang besar.....” (Subjek Cicha)

“ ...sistem hierarki itu eemmm...maksudnya ya untuk membuat junior hormat ke seniornya... artinya seniornya mesti bisa jadi contoh kan..... iya banyak juga kenyataannya yang gak seperti itu...senior mencontohkan yang gak bener...tapi itu kembali ke pribadinya juga ...” (Subjek Desi).

\section{f. Empati}

Kehidupan taruna yang berada 24 jam penuh di asrama/kampus, membuat interaksi antar taruna pun lekat. Tidak hanya dengan sesama taruna remaja (junior) namun juga dengan taruna senior. empati di sini dilihat dari sejauh mana partisipan penelitian ini menempatkan dirinya pada posisi orang lain (taruna senior) dengan pemberlakuan aturan yang diterapkan.

“...senior itu tujuannya emang hanya buat menekan para juniornya... Itu seperti ajang untuk membuat senior tampak wibawa...makanya aturannya juga banyak yang gak bener... Kalau masih aturan yang masuk akal untuk mendisiplinkan sih mendingan, tapi kalau disuruh jalanin hukuman gak bener, push-up lima puluh kali, lari jingkring (loncat satu kaki), itu gak ada unsur pembinaannya" (Subjek Adi)

"yang tadinya saya gak disiplin jadi terasa banget sih di sini, dipaksa untuk disiplin. Sebagian senior ada yang sok gagah, menyalahgunakan wewenang... tapi itu tergantung lagi sama pribadinya... 
kalau saya, ya liat-liat dulu...biasanya kalau dihukum emang ada pelanggaran yang dibuat, meskipun itu pelanggaran gak sengaja " (Subjek Budi)

“......masuk di STP ini emang mesti siap-siap ditempa. Lingkunganku sebelumnya $u d a h$ membuatku emang harus tangguh....jadi kalau kakak taruni di sini galak, aku bayangin aja lah mereka itu seperti pengganti orang tua, yang suka ngatur dan cerewet, tapi maksudnya baik....iya melewatinya susah sih...banyak salah paham juga, namanya sesama cewek...dengan kakak taruni pun begitu... eeh... urusan perasaan juga....tapi aku banyak berlatih di sini...di sini gak ada tempat buat cengeng berlama-lama ...." (Subjek Cicha)

“...pernah kejadian dihukum membersihkan kamar mandi... semua kamar mandi...karena kesalahan sepele aja, gak sengaja mecahin gelas senior...ya udah abis lah dikenai sanksi...ya senior itu taunya menghukum dengan cara seperti itu...seperti yang udah-udah ...harusnya bisa diusulkan supaya ada metode sanksi yang lebih mendidik...tapi kalau mau berubah, semua taruni senior, termasuk senior-senior di atasnya juga mesti siap berubah juga kan.......” (Subjek Desi).

\section{g. Kemampuan Menjangkau}

Kemampuan menjangkau (reaching out) merupakan kapasitas partisipan untuk memperkirakan risiko yang akan mereka dapatkan serta meraih aspek positif dari peristiwa yang mereka jalani. Masa adaptasi terhadap sistem pendidikan telah dilalui partisipan selama kurun satu semester awal setelah mereka menjadi taruna. Sebagian partisipan telah memiliki gambaran mengenai risiko ke depan mengikuti pendidikan di STP serta meraih aspek positif di dalamnya.

“...kalau saya sampe sekarang masih jenuh menghadapi sistem yang ada....ngatasinnya, ya... kadang kabur keluar...itu pelarian sesaat aja ...iya ngajak teman...kalau jenuh $u d a h$ kurang, balik lagi...pinter-pinter aja caranya supaya gak ketauan sama yang jaga...gak mungkin juga diawasi terus 24 jam, ada aja celahnya...." (Subjek Adi)

" awalnya emang tertekan banget ya di sini...tapi udah satu semester berlalu, sekarang udah ketemu selanya...udah tau cara-caranya untuk menghadapi senior...dan rasanya tekanan juga udah berkurang... di kelas juga udah bisa lebih konsentrasi mendengarkan kuliah dari dosen ... intinya ya kita aktif aja deh kalau pengen maju.... "(Subjek Budi)

“...satu semester ini Alhamdulillah IP saya lumayan bagus, puas rasanya......karena perjuangannya banyak...fasilitas saya gak sebaik teman-teman lain....dan sekarang juga udah lebih kompakan sama teman seangkatan...jadi udah bisa lebih banyak liat sisi bagusnya pendikan di sini..." (Subjek Cicha)

“...di sini kan banyak peluang untuk mengikuti kegiatan minat bakat... ada drumb band, tenis, renang, banyak... jadi gak cuma kuliah, bisa lebih ningkatin kemampuan......ada juga pengajian di masjid, lumayan macem-macem kegiatannya...jadi bisa banyak belajar hal lain juga ..." (Subjek Desi).

\section{Analisis Inter-Subjek}

Berdasarkan penggalian data yang telah dilakukan, di bawah ini disajikan analisis inter-subjek, yang meliputi analisis tujuh faktor resiliensi dan faktor protektif resiliensi. Data tersaji dalam ringkasan tabel sebagai berikut: 


\section{Analisis Faktor Resiliensi}

Tabel 2. Analisis Faktor Resiliensi Partisipan

\begin{tabular}{|c|c|c|c|c|}
\hline \multirow{2}{*}{ FAKTOR } & \multicolumn{4}{|c|}{ Subjek } \\
\hline & Adi & Budi & Cicha & Desi \\
\hline Regulasi emosi: & Kurang & Cukup & Baik & Cukup \\
\hline Tetap tenang & $\begin{array}{l}\text { Gusar, merasa ingin } \\
\text { marah }\end{array}$ & $\begin{array}{l}\text { Marah tapi men- } \\
\text { coba mengatasi }\end{array}$ & $\begin{array}{l}\text { Tetap tenang meski } \\
\text { kecewa }\end{array}$ & $\begin{array}{l}\text { Gusar, dialihkan } \\
\text { pada hal lain }\end{array}$ \\
\hline $\begin{array}{l}\text { Kendali } \\
\text { Impuls: }\end{array}$ & Kurang & Cukup & Baik & Cukup \\
\hline $\begin{array}{l}\text { Perubahan dan } \\
\text { dorongan emosi }\end{array}$ & Disalurkan langsung & $\begin{array}{l}\text { Melihat saat yang } \\
\text { tepat }\end{array}$ & $\begin{array}{l}\text { Disalurkan lewat cara } \\
\text { lain }\end{array}$ & $\begin{array}{l}\text { Melihat saat yang } \\
\text { tepat }\end{array}$ \\
\hline Optimisme: & Cukup berkembang & Cukup berkembang & Berkembang & Cukup berkembang \\
\hline $\begin{array}{l}\text { Melihat masa } \\
\text { depan }\end{array}$ & $\begin{array}{l}\text { Masalah akan } \\
\text { selesai }\end{array}$ & $\begin{array}{l}\text { Masalah akan } \\
\text { selesai }\end{array}$ & $\begin{array}{l}\text { Masalah menempa } \\
\text { mental menjadi lebih } \\
\text { baik }\end{array}$ & $\begin{array}{l}\text { Masalah bersifat } \\
\text { sesaat }\end{array}$ \\
\hline Efikasi diri: & Cukup & Cukup & Baik & Cukup \\
\hline $\begin{array}{l}\text { Keyakinan untuk } \\
\text { memecahkan } \\
\text { masalah }\end{array}$ & $\begin{array}{l}\text { Yakin dapat meme- } \\
\text { cahkan masalah }\end{array}$ & $\begin{array}{l}\text { Yakin dapat meme- } \\
\text { cahkan masalah }\end{array}$ & $\begin{array}{l}\text { Masalah merupakan } \\
\text { proses pendewasaan }\end{array}$ & $\begin{array}{l}\text { Yakin dapat meme- } \\
\text { cahkan masalah }\end{array}$ \\
\hline $\begin{array}{l}\text { Analisis Penye- } \\
\text { bab: }\end{array}$ & Kurang & Cukup & Baik & Kurang \\
\hline $\begin{array}{l}\text { Identifikasi penye- } \\
\text { bab masalah }\end{array}$ & $\begin{array}{l}\text { Sistem hierarki } \\
\text { sebagai penyebab } \\
\text { masalah }\end{array}$ & $\begin{array}{l}\text { Ada kontribusi } \\
\text { antara sistem dan } \\
\text { pribadi taruna }\end{array}$ & $\begin{array}{l}\text { Reaksi positif terha- } \\
\text { dap masalah }\end{array}$ & $\begin{array}{l}\text { Sistem pembi- } \\
\text { naan taruna perlu } \\
\text { dikoreksi }\end{array}$ \\
\hline Empati: & Kurang & Cukup & Baik & Cukup \\
\hline $\begin{array}{l}\text { Memahami orang } \\
\text { lain }\end{array}$ & $\begin{array}{l}\text { Taruna senior bersi- } \\
\text { kap menekan }\end{array}$ & $\begin{array}{l}\text { Sikap yang ada } \\
\text { sebagai akibat dari } \\
\text { sistem }\end{array}$ & $\begin{array}{l}\text { Taruna senior juga } \\
\text { berada dalam } \\
\text { tekanan }\end{array}$ & $\begin{array}{l}\text { Sikap yang ada } \\
\text { sebagai akibat dari } \\
\text { sistem }\end{array}$ \\
\hline Kemampuan & Kurang & Cukup & Cukup & Cukup \\
\hline $\begin{array}{l}\text { Menjangkau: } \\
\text { meningkatkan } \\
\text { kualitas }\end{array}$ & $\begin{array}{l}\text { Kurang mampu } \\
\text { menerima }\end{array}$ & $\begin{array}{l}\text { Mampu melihat hal } \\
\text { yang harus diper- } \\
\text { baiki }\end{array}$ & $\begin{array}{l}\text { Mampu melihat hal } \\
\text { yang harus diperbaiki }\end{array}$ & $\begin{array}{l}\text { Mampu melihat } \\
\text { hal yang harus } \\
\text { diperbaiki }\end{array}$ \\
\hline
\end{tabular}


Tabel 3. Analisis Faktor Protektif Resiliensi Partisipan

\begin{tabular}{|c|c|c|c|c|}
\hline \multirow{2}{*}{$\begin{array}{l}\text { Faktor } \\
\text { Protektif }\end{array}$} & \multicolumn{4}{|c|}{ Subjek } \\
\hline & Adi & Budi & Cicha & Desi \\
\hline \multirow[t]{2}{*}{ Individu } & $\begin{array}{l}\text { Indeks Prestasi (IP) } \\
\text { cukup baik }\end{array}$ & IP baik & IP relatif paling tinggi & IP baik \\
\hline & $\begin{array}{l}\text { Memiliki teman } \\
\text { dekat/sahabat di } \\
\text { kampus }\end{array}$ & $\begin{array}{l}\text { Akrab dengan } \\
\text { teman satu } \\
\text { kamar }\end{array}$ & $\begin{array}{l}\text { Memiliki teman satu } \\
\text { kamar yang kompak- } \\
\text { Dukungan moral dari } \\
\text { saudara alumni STP }\end{array}$ & $\begin{array}{l}\text { Memiliki teman bercerita } \\
\text { sepenanggungan }\end{array}$ \\
\hline Komunitas & $\begin{array}{l}\text { Aktif dalam komu- } \\
\text { nitas dari daerah } \\
\text { yang sama }\end{array}$ & $\begin{array}{l}\text { Ikut serta dalam ke- } \\
\text { giatan minat bakat } \\
\text { (olah raga) }\end{array}$ & $\begin{array}{l}\text { Populer di antara } \\
\text { antara teman-teman } \\
\text { lainnya, sebagai per- } \\
\text { wakilan senat kelas }\end{array}$ & $\begin{array}{l}\text { Aktif pada kegiatan } \\
\text { ekstra kurikuler kam- } \\
\text { pus }\end{array}$ \\
\hline Keluarga & $\begin{array}{l}\text { Keluarga mendu- } \\
\text { kung }\end{array}$ & $\begin{array}{l}\text { Keluarga mem- } \\
\text { berikan dukungan } \\
\text { penuh }\end{array}$ & $\begin{array}{l}\text { Keluarga sebagai } \\
\text { penyemangat } \\
\text { Keluarga memberi } \\
\text { dukungan moral }\end{array}$ & $\begin{array}{l}\text { Keluarga mengharap- } \\
\text { kan keberhasilan }\end{array}$ \\
\hline
\end{tabular}

Keempat subjek dalam penelitian ini memiliki tingkat resiliensi yang bervariasi. Secara umum dapat dikatakan bahwa subjek Cicha memiliki tingkat resiliensi yang relatif paling baik, diikuti oleh Budi, Desi dan Adi. Pada masing-masing subjek, sumbangan 7 (tujuh) faktor resiliensi juga bervariasi antara satu faktor dengan faktor lainnya.

Pada faktor regulasi emosi, Cicha tampil sebagai pribadi yang tenang meskipun menghadapi kendala penyesuaikan diri pada sistem pembelajaran di STP. Ia juga mampu melakukan penyelesaian persoalan dengan cara mengalihkan kekecewaan tersebut pada hal-hal lain yang lebih positif. Hal tersebut ditunjang oleh rasa optimismenya yang kuat, dengan keyakinan bahwa masalah merupakan cara untuk menempa diri seseorang menjadi lebih baik. Reaksi yang positif terhadap persoalan penyesuaian diri ini membuat Cicha memiliki efikasi-diri yang baik serta berupaya melakukan langkah-langkah terarah untuk meningkatkan kualitas dirinya.

Sementara pada subjek Budi dan Desi, keduanya telah dapat melakukan pengendalian emosi pada kategori cukup. Meski emosi negatif seperti marah, gusar dan kecewa menghampiri, namun mereka mencoba mengatasinya dengan menyalurkannya pada waktu yang tepat. Mereka juga cukup optimis berpikir dan melihat persoalan yang dapat akan selesai dengan masa adaptasi yang dilalui. Dalam analisis-penyebab (causal analysis) mereka masih melihat penyebab persoalan adalah sistem yang selama ini berlaku sehingga banyak menyoroti sistem yang berjalan sebagai penyebab utamanya. Kondisi-kondisi tersebut pada akhirnya membuat mereka melihat dapat melihat hal-hal yang harusnya dapat diperbaiki untuk pembentukan sistem yang lebih baik dalam proses pendidikan yang akan datang.

Subjek Adi yang memiliki tingkat resiliensi paling rendah dibandingkan dengan partisipan lainnya, belum cukup stabil dalam melakukan pengendalian diri. Meski cukup optimis dalam melihat masalah dan merasa yakin bahwa masalah dapat diatasi (efikasi diri cukup berkembang), namun emosinya tampil intens dan membuatnya menyalurkannya secara langsung. Ia juga menganggap sistem pendidikan yang ada menjadi penyebab persoalan ini terjadi. Sikap taruna senior yang menekan juga membuatnya tidak dapat berpikir matang dalam bertindak. Sikap empati Adi tampak kurang, sehingga ketika berhadapan dengan persoalan yang ada, ia lebih banyak menimpakan kesalahannya pada pihak lain. 
Tinjauan berdasarkan faktor protektif, keempat subjek memiliki lingkungan protektif yang positif. Hal tersebut terlihat baik pada aspek individu, aspek komunitas dan aspek keluarga. Sebagai taruna, mereka dikenal memiliki Indeks Prestasi yang cukup baik, dengan tingkat variasi tertentu. Selain itu, partisipan juga aktif pada berbagai kegiatan di kampus, baik kegiatan yang difasilitas oleh kampus seperti kegiatan minat dan bakat (ekstra kurikuler), kegiatan keagamaan, maupun kegiatan komunitas daerah. Faktor keluarga juga memberikan dukungan penuh terhadap keberhasilan studi partisipan dalam menempuh pendidikan di STP. Dukungan keluarga ini menjadi salah satu faktor penting yang membuat partisipan bertahan menjalani pendidikan di STP meskipun harus menempuh masa adaptasi cukup berat.

\section{DISKUSI}

Temuan dalam penelitian ini mendukung pernyataan yang dikemukakan oleh Reivich dan Shatte (2002), yang menyatakan bahwa hampir tidak ada satupun individu yang secara keseluruhan memiliki tujuh faktor resiliensi merata sama baiknya pada keseluruhan dimensi. Sebagian besar individu memiliki tingkat resiliensi yang tinggi pada faktor-faktor tertentu; namun juga tingkat resiliensi yang lebih kurang pada faktor-faktor lainnya. Faktor latar belakang/asal budaya yang berbeda, sebagaimana data yang diambil diperoleh dalam penelitian ini, juga tidak mencerminkan secara langsung perbedaan tingkat resiliensi. Hal ini sejalan dengan pernyataan dari The National Research Council and Institute of Medicine yang menyebutkan bahwa karakteristik resiliensi tampil secara konsisten pada berbagai kelompok lintas budaya (Eccles \& Gootman, 2002, dalam Long, Shelley L, 2011). Meskipun ada beberapa perbedaan faktor-faktor resiliensi pada faktor tertentu, namun latar belakang budaya bukan merupakan penentu perbedaan tersebut. Perbedaan tersebut lebih disebabkan oleh karakteristik kepribadian, termasuk di dalamnya cara individu menyelesaikan permasalahan dalam hidupnya.

Penelitian ini dilakukan terhadap taruna yang tinggal di lingkungan asrama, dengan tuntutan sosial, maupun tuntutan akademis tertentu. Sebagai taruna, mereka memiliki kesadaran penuh mengenai tujuan mereka berada di STP. Meskipun menghadapi tekanan dalam menjalani proses pendidikan, namun orientasi terhadap masa depan serta pencapaian akademis, membuat partisipan dalam penelitian ini memiliki resiliensi yang positif. Hal ini terutama terlihat pada faktor efikasi diri dan optimisme. Beberapa penelitian menyajikan hasil yang serupa, yang menunjukkan bahwa fokus yang positif dan kuat terhadap masa depan berkorelasi dengan identifitas diri yang sehat, pencapaian prestasi akademis, serta tingkah laku yang berisiko secara kesehatan (Mastern \& Coatsworth, 1998; Quinton, Pickeles, Maughan \& Rutter, 1993; Selligman, 2002; Snyder, Rand \& Sigmon, 2002, dalam Long, Shelley L, 2011). Di samping itu, partisipan penelitian ini memiliki IPK (Indeks Prestasi Kumulatif) yang relatif baik. IPK yang baik ini menunjukkan keterampilan individu dalam menyelesaikan problematika selama masa studi, yang berpengaruh pada tingkat resiliensinya (Hidayati, Rejeki, Laily, 2011 dalam Yulianto, 2011).

Faktor protektif yang mendukung taruna dalam penelitian ini juga menjadi aspek yang membuat resiliensi mereka berkembang positif. Selain faktor protektif yang bersifat individu, faktor protektif berupa komunitas asal daerah menjadi pendukung taruna untuk bertahan di STP (Daging, I Ketut, 2012). Keterlibatan taruna dalam komunitas sesuai asal daerahnya masing-masing menjadi tempat untuk berbagi persoalan, termasuk memberikan bantuan bila ditemui kesulitan dalam hal adaptasi. Selain faktor komunitas, faktor protektif keluarga ternyata menjadi aspek yang paling penting dalam mendukung taruna untuk bertahan dan menyelesaikan persoalannya di STP. Hal ini sejalan dengan hasil penelitian Kinanthi (dalam Yulianto, 2011) yang menyatakan bahwa keluarga memainkan peranan penting dalam menghadapi situasi yang sulit. 
Faktor protektif keluarga terlibat dalam memprediksikan proses adaptasi seseorang ataupun tingkat resiliensi individu yang menghadapi situasi menantang (Luthar, 1991, dalam Yulianto, 2011).

\section{SIMPULAN \& SARAN}

\section{Simpulan}

Tingkat resiliensi antara partisipan yang diteliti cukup bervariasi antara satu dengan yang lainnya. Meskipun pada akhirnya terdapat kesimpulan tertentu tentang tingkat resiliensi mereka, namun faktor-faktor yang mendukung resiliensi partisipan berbeda-beda. Di antara faktor-faktor resiliensi tersebut, aspek efikasi-diri dan optimisme pada keseluruhan subjek menunjukkan respons yang secara umum positif. Kedua faktor ini merupakan faktor paling kuat yang menunjang partisipan tetap bertahan untuk mengikuti proses pendidikan yang berlangsung dan melaluinya secara bertahap, karena meyakini pada akhirnya persoalan yang dihadapi akan dapat diselesaikan.

Selain ketujuh faktor resiliensi yang telah dipaparkan di atas, maka faktor protektif juga memiliki pengaruh yang signifikan. Tuntutan akademik dan sosial yang mereka hadapi di STP dapat mereka sikapi dengan dukungan sumber daya dan karakteristik yang positif dari individu. Sesuai dengan pendapat Hidayati dkk, (dalam Yulianto, 2011) yang menyebutkan bahwa keterampilan individu dalam menyelesaikan problematika selama masa studi berpengaruh pada tingkat resiliensinya. Partisipan yang memiliki karakteristik pribadi yang positif akan lebih tangguh ketika menghadapi persoalan yang muncul selama mereka mengikuti masa pendidikan. Selain itu, dukungan keluarga juga merupakan faktor yang menentukan, di samping faktor sumber daya pribadi (Luthar 1991, dalam Yulianto, 2011). Kontak yang mereka jalin secara intens dengan keluarga juga menjadi salah satu faktor yang membuat mereka mencoba bertahan meskipun di saat tertentu merasa bahwa tuntutan lingkungan pendidikan yang dialami terasa berat. Dukungan keluarga menjadi penyemangat bagi mereka karena ketidakinginan untuk mengecewakan harapan yang sudah ditanam.

Selain faktor protektif individu, maka faktor protektif berikutnya berupa jaringan sosial eksternal dan komunitas sosial, menjadi faktor pendukung dalam memperkuat cara coping yang adaptif terhadap persoalan yang terjadi. Sebagai taruna yang berasal dari daerah, mereka memiliki komunitas yang berasal dari daerah yang sama dari berbagai propinsi di Indonesia. Peran komunitas sosial yang memiliki kesamaan asal daerah ini menjadi faktor yang mendukung mereka untuk mampu melalui proses adaptasi yang berlangsung, sehingga mereka dapat menyesuaikan diri dengan tuntutan yang ada dan kemudian mengambil peran pendukung yang sama untuk adik-adik kelas pada tahun akademik berikutnya.

Faktor protektif keluarga menjadi aspek yang paling penting bagi taruna. Ketika menghadapi beratnya persoalan di kampus, salah satu hal mendasar yang membuat taruna tetap bertahan adalah dukungan positif keluarga untuk bersikap tangguh menghadapi dinamika kehidupan kampus. Dukungan tersebut juga mengembangkan rasa tanggung jawab taruna dalam bentuk keinginan untuk membahagiakan orangtua/ keluarga serta menyelesaikan pendidikannya hingga mencapai gelar sarjana.

\section{Saran}

Saran teoritis maupun saran praktis berdasarkan hasil penelitian ini adalah sebagai berikut:

1. Penelitian resiliensi pada taruna pumakan di STP ini menggunakan teknik kualitatif dengan jumlah partisipan yang terbatas. Untuk penelitian berikutnya, dapat digabungkan dengan pendekatan 
kuantitatif, sehingga dapat memperoleh hasil penelitian yang lebih beragam dengan tingkat generalisasi yang lebih besar.

2. Penelitian ini mengambil subjek yang memiliki IPK relatif baik. Untuk ke depan, dapat diusulkan pengambilan data pada taruna yang memiliki persoalan akademis, sehingga dapat dilihat pula dinamika resiliensi yang berlangsung.

3. Mengingat STP memiliki asal daerah dari berbagai provinsi, maka untuk penelitian lanjutan, disarankan agar dapat mengikutsertakan subjek penelitian yang berasal dari latar belakang provinsi yang lebih beragam, sehingga lebih merepresentasikan karakteristik taruna STP.

4. Resiliensi merupakan hal penting yang menjadi kunci keberhasilan taruna dalam mengikuti pendidikan di STP. Pihak kampus/bagian pembinaan taruna dapat mempertimbangkan untuk memasukkan faktor resiliensi ini sebagai salah satu proses pembinaan pada lingkungan taruna. Penanaman resiliensi dapat dilakukan dalam bentuk pelatihan berkala, sesi konseling kelompok ataupun dimasukkan dalam kurikulum pengajaran khususnya pada materi soft skills.

\section{DAFTAR PUSTAKA}

Atwater, E. \& Duffy, K.G. (1997). Psychology for living. USA: Prentice-Hall, Inc.

Chen, J. D. \& George, R. A. (2005). Cultivating resilience in children from divorced families.

Daging, I Ketut. (2012). Sistem Pembinaan Taruna Sekolah Tinggi Perikanan. Jakarta: STP Press.

Greef, A. (2005). Resilience: personal skills for effective learning. UK: Crown House Publishing Ltd.

Isaacson, B. (2002). Characteristics and enhancement of resiliency in young people: a research paper. http://www.uwstout.ede/lib/thesis/2002/2002isaacsonb.pdf).

Long, Shelley L. (2011). The relationship between religiousness/spirituality and resilience in college students. ProQuest Dissertations and Theses; 2011. ProQuest.

Luthans, F., Vogelgesang, G. R. \& Lester, P. B. (2006). Human resource development review : developing the psychological capital of resiliency.

Poerwandari, K. (2011). Pendekatan Kualitatif untuk Penelitian Perilaku Manusia. Depok: LPSP3 UI.

Reivich, K. \& Shatte, A. (2002). The resiliensce factor: 7 essential skills for overcoming life's inevitable Obstacles.USA: Broadway Books.

Rutter, M. (1987). Psychosocial Resilience and Protective Mechanism. American Journal of Orthopsychiatry, Vol. 57, p. 316-331.

Siebert, A. (2005). The resiliency advantage: master change, thrive under presure, and bounce back from setbacks. San Fransisco: Berrett-Koehler Publisher, Inc.

Yulianto, Aries, (editor) (2011). The international conference on psychology of resilience. Depok: LPSP3 UI.

\section{Internet}

Sejarah singkat Sekolah Tinggi Perikanan (STP). Diperoleh dari http://stp. kkp.go.id. Diunduh pada tanggal 15 Februari 2013 jam 10.20 wib. 
